American Association of Hispanics in Higher Education, Inc.

\title{
Models of Leadership Institutes for Increasing the Number of Top Latino Administrators in Higher Education
}

\author{
David J. León \\ California State University, Sacramento \\ Carlos Nevarez \\ California State University, Sacramento
}

This Scholarly Paper was commissioned for the 2nd Annual Conference of the American Association of Hispanics in Higher Education, 2007. 


\begin{abstract}
The percentage of Latinos in top university administration lags far behind that in the nation overall. How can we increase their numbers? One answer is leadership institutes. This article examines these institutes in general and those addressing minorities in particular, with an eye to presenting models that may aid future Latino leadership institutes. It explains the need for these programs and describes four long-established institutes and four more addressing minorities.
\end{abstract}

Keywords: Latino: leadership development; leadership institutes; demographic trends; educational status, leadership career path 
Each day Latinos become a greater share of the U.S. population, and their paucity in the universities - as students, professors, and high-level executives - becomes more conspicuous. Latino college presidents are particularly important, since they can help elevate the current low Latino retention rates and pass on valuable information to business and political leaders. Both functions will be critical, because Latino college graduates are more and more vital to maintaining our knowledge economy. Yet only about one in 20 of college presidents today is Latino. Their numbers must triple if they are to reflect the Latino presence in U.S. society overall.

How can we increase Latinos in top university administration? Leadership institutes are one solution. Since the 1960s they have helped thousands of aspirants prepare for top university positions through instruction, mentoring, and eyewitness experience. These programs typically instruct participants about key executive tasks such as fundraising, building a collaborative environment, working with internal and external constituents, and creating a vision. At the conclusion, participants are better prepared to seek executive positions, given their deeper insight into the work itself and door-opening basics like the letter of intent, curriculum vita, and interviews.

Though some Latinos have passed through these institutes and benefited, people of color face special challenges in climbing the administrative ladder. As a result they gain unusual advantages from the programs oriented toward them. These newer institutes address the traditional 
subjects, but also highlight the particular issues Latinos face and give participants an opportunity to gain constructive feedback and support from seasoned leaders (Chen \& Velsor, 1996). A distinctive feature of minorityfocused institutes is attention to preparing administrators who are alert to the needs of underserved communities. These programs encourage participants to lead the organization through change, to create or adapt structures to meet the growing challenges and opportunities of diversity.

This article examines leadership institutes in general and those addressing minorities in particular, with an eye to presenting models that may aid future Latino-specific institutes. It details the need for these programs and describes four long-established institutes and four more addressing minorities. It also notes the need for firmer philanthropic support for the latter.

The Catchup Game: The Need for More Latino Administrators

On almost every statistical front, Latinos in the general population are outpacing Latino college presidents. Latinos are the largest minority group in the nation. In 2005 they numbered 42.7 million and comprised 14.4 percent of the population, while blacks were 12.8 percent and whites 80.2 percent. $^{1}$ Indeed, there are now more Hispanics in the United States than in Spain.

Overall, the Latino population is growing four times faster than the nation's, and about one of every two people added to the nation's population in the year between July 1, 2004, and July 1, 2005, was Hispanic. ${ }^{2}$ At this rate, some 103 million Latinos will live in the United States by 2050 (or 24 percent 
of the projected total), about the population of Mexico today (U.S. Census, 2006).

Latinos are also young, ${ }^{3}$ and in 2000 they comprised 17.0 percent of all people under 18 , compared to 61.2 percent for whites and 14.8 percent for African Americans (Martinez, 2005). In other words, a demographic youth bulge is approaching the university, and more and more Latino youth will be knocking on college doors. In some areas the demand will run high. In California, for instance, Latinos now constitute 45 percent of all public school students, up from 34 percent ten years ago.

Despite the fast-rising numbers of Latinos in our society and schools, Latino top administrators remain uncommon in higher education. As of 2006 they comprised only 5 percent of college or university presidents, compared to 6 percent for blacks and 86 percent for whites (June, 2007). ${ }^{4}$ In other words, their percentage of presidencies is about a third of their percentage in the U.S. population. Much catchup lies ahead.

Moreover, most Latino presidents serve in public two-year colleges. As one ascends from community colleges to the elite, research universities, one finds far fewer Latino high administrators. As of Fall 2003, Hispanics occupied 5.3 percent of the executive positions - a much broader category than presidents - at public two-year institutions, compared to 3.7 percent at public four-year institutions (U.S. Department of Education, 2005). California's three-tier system of higher education illustrates the pattern. Currently, only one of the ten University of California campuses has a 
Hispanic chancellor and just three Latinos serve as presidents at the 23campus California State University. However, 30 are CEO-level leaders at the 109 campuses of the California Community College system (León \& Nevarez, 2006). Overall, says Martinez (2005), "One can count on one hand the number of Latinos who have held presidencies at research institutions" (p. 18).

Homogeneity in administration tends to perpetuate itself. Hence Vaughan (2004) observes that presidents must actively assume responsibility for developing minority high-level executives. "Without diversity at the top," he states, "institutions face stagnation and loss of fresh ideas and new perspectives that will keep them vibrant, responsive, and intellectually challenging" (p. B14).

\section{The Problematic Leadership Ladder}

Why are Hispanic presidents so rare? The traditional ladder to a presidency has many steps, which typically include positions as assistant professor, full professor, chair, dean, provost, and vice president. A graduate degree is virtually essential, and 55.6 percent of presidents possess a $\mathrm{Ph} . \mathrm{D}$. while 20.8 percent hold an Ed.D. (Corrigan, 2002).

Yet this route can be problematic for Latinos. A doctorate is just the start, and once in the university hierarchy, people of color move up more slowly than whites. In 2003, Latinos were 2.9 percent of full-time tenure-track U.S. faculty, while 84.2 percent were white, 5 percent black, and 7.5 percent Asian (U.S. Department of Education, 2003-04). Delgado-Romero, Flores, 
Gloria, Arredondo, and Castellanos (2003) state that Latino faculty lie at the bottom of the faculty pyramid. Their analysis reveals that there are more Latino instructors, lecturers, and non-tenure line faculty $(6,187)$ than tenuretrack assistant $(4,237)$, associate $(3,161)$, or full $(2,913)$ professors. Furthermore, they found that, while the tenure rate for all faculty is 73 percent, 75 percent of white faculty gain tenure compared to 64 percent of Latino faculty. Ultimately, Latinos account for 1.4 percent of full professors (Harvey, 2003), about half the percentage of all tenure-track faculty.

This relative absence of Latino faculty occurs despite their invaluable contributions. Through their research, teachings, and involvement with the campus and wider community, they bring an array of perspectives which illuminate issues of equity, culture, and society from multiple angles. Significant research confirms that the presence of Latino faculty promotes equity in higher education. Among their positive impacts, they increase the academic achievement of Latinos and other students of color (Berlak \& Moyenda, 2001; Tatum, 1997; Shoem, Frankel, Zuniga, \& Lewis, 1993; Ladson-Billings, 1994). In addition, Latino faculty directly improve educational quality, better prepare students to live and work in an increasingly global society, expose students to a broader range of scholarly viewpoints, and through their teaching and research advance the progress of Latino students and community (Medina \& Luna, 2000; Nieves-Squires, 1991; Turner \& Myers, 2000; Nevarez \& Borunda, 2007).

But what accounts for the difference between the 1.4 percent of full 
professors who are Latino and the 5 percent of presidents? Though studies are lacking, the answer is almost certainly that many Latino presidents in two-year colleges come directly from student affairs rather than the academic side. Hence, in the HACU Latino/a Higher Education Leadership Institute, about three out of every four enrollees work in student affairs. Student affairs professionals almost never become presidents of four-year universities, but the two-year colleges are more responsive to community needs.

The small number of Latino professors remains a major obstacle to increasing Latino leadership, since the more diverse the faculty today, the more easily administration can become diverse tomorrow (Smith \& Moreno, 2006). Even so, some may construe the perspectives of Latinos as challenging and even hostile to the institution, a perception which can reduce their intake into administrative positions. Some observers say the slow upward advancement of Latinos implies devaluation of their potential and a belief that they have greater need to prove themselves. ${ }^{5}$ Haro and Lara (2003) add that Hispanics suffer the limiting effects of poor representation in higher circles in general, and especially on the boards that make presidential appointments.

\section{The Education Hurdles}

Critically, many talented Latinos never reach the first rung of the ladder. The most serious barriers for Hispanics lie in the education system, where Latino students face an obstacle course from preschool through college. Latinos typically come from poor families in areas whose high schools have 
low graduation and college entrance rates. They face numerous challenges:

- Low-caliber schools. Most Latinos attend schools that offer fewer rigorous academic courses. Their high schools are much more likely to be large, to have a high student-to-teacher ratio, and to have a sizeable portion of students from impoverished families. Studies show that all these factors correlate with lower student performance (Fry, 2005).

- Low high school graduation rate. Latinos are significantly less likely to complete high school. Though high school graduation rates are famously hard to ascertain, one well-known study estimates that 53.2 percent of Latinos finish secondary school compared to 74.9 percent of whites (Orfield, Losen, Wald, \& Swanson, 2004).

- Less effective college preparation. Latino families are much less likely to know about financial aid for their children, and they can less afford SAT and ACT preparation courses, which improve scores and boost chances of getting into college. In addition, the campus culture can seem alien and daunting to young Latinos with little exposure to it.

- Channeling to two-year institutions. Latino students who do enter higher education enroll disproportionately in community colleges and fail to transfer to four-year universities. Of all Latinos in postsecondary education during 1999-2000, 60 percent were studying in two-year colleges (León, 2003). 
- Low college graduation rate. In 2005, just 12 percent of Latinos age 25 years and older had received a bachelor's degree or higher, compared to nearly 18 percent of blacks and more than 30 percent of comparable whites (U.S. Census Bureau, 2005). Yet Latinos with a bachelor's earn between 63 percent and 108 percent more than Latinos who only graduate from high school (U.S. Census Bureau, 2006).

- Reduced presence in graduate school. Among Latinos who gain their bachelor's degrees, relatively few attend graduate school, a vital steppingstone to a career in college administration.

These are complex problems that require multifaceted solutions, but the end of the cycle of poverty begins at the college graduation ceremony.

\section{The Impact of Latino Administrators}

Though the literature on the effect of Latino senior administrators remains scant, the success of Latino faculty and the power of presidents imply a major impact. For instance, Latino presidents serve as crucial role models for Hispanic youth in school, assuring them that they too can achieve high position and promoting their quest to try. Even the most capable white presidents cannot perform this function. More broadly, presidents can play a key role in changing campus attitudes by making institutions more inclusive and hospitable to Latinos (Haro, 2005). And since Latino administrators better grasp the needs of Latino students, often because of shared background, they 
tend to have more insight into retaining them in college.

For example, Chancellor France A. Córdova continues to build the UC Riverside reputation for diversity. The university attracts minorities through active recruitment in the community, summer programs to help ease prospective students into campus life, and remedial courses in math and English. UC Riverside has been particularly successful in reaching black and Latino students. In 2006-07, the undergraduate student body was 25.1 percent Latino, 7.1 percent black, 43 percent Asian American, and 18.7 percent white. By comparison, in 2005 the University of California student body overall was 14.3 percent Latino, 3.1 percent black, 39.9 percent Asian American, and 35.8 percent white. Chancellor Córdova took office in 2002 and may not be wholly responsible for this success, and the Riverside area has greater concentrations of Latinos and blacks than the state overall (Paddock, 2007). Even so, the efforts are impressive.

Latino college presidents also directly benefit the larger community. In addition to molding attitudes on campus, presidents typically become part of the network of local leaders, through fundraising contacts or service on important boards and commissions. They discuss key issues with these decision makers and help shape attitudes. In fact, since Latinos remain somewhat uncommon in these networks, presidents can become unusually important pipelines of information and insight to them. They can therefore affect policy at the local, state and national levels. 


\section{The Need for Latinos in the Knowledge Economy}

The United States will require more Latino presidents - and by extension Latino leadership programs - since Latino college graduates are crucial to our continued national prosperity. This issue transcends minority needs and touches everyone in the country. We live in a knowledge economy fueled by sophisticated skills, the kind our universities provide. Yet Baby Boomers are starting to leave the workforce, and more people will retire in the coming years than will enter it. At the same time, more and more foreign students - many of whom have made key contributions to our economy—are returning to their own countries. So the need for talent will intensify.

To sustain our economic base, we will turn to the growing minority population. However, as noted above, only 12 percent of Latinos 25 or older had graduated from college by 2004, compared to 32 percent of U.S. nonminorities. And only 3.9 percent of U.S. scientists and 5.1 percent of engineers with a doctorate were Latino as of 2003 (National Science Foundation, 2006). As future-oriented businesspeople recognize, improving these numbers is a matter of national urgency, ${ }^{6}$ and hiring more Latino leaders in higher education is an important step toward this goal. A recent U.S. government report underscores the need:

Too few Americans prepare for, participate in, and complete higher education — especially those underserved and nontraditional groups who make up an ever-greater proportion of the population. The nation will rely on these groups as a major source of new workers as demographic 
shifts in the U.S. population continue. (U.S. Department of Education, 2006, sec.1:7)

This phenomenon will also affect college administration itself, since presidents have grown older. Their average age in 2006 was 60, up from 52 in 1986. In 2006 just 8 percent were 50 or under, while in 198642 percent were (June, 2007). Hence a major turnover will take place in the next decade as large numbers of them retire. The new job openings will provide an opportunity to hire Latino presidents and better address the wider demand for minority graduates in general.

Given the pressing need, we may wish to look beyond academic affairs and tap more Latino executives directly from student affairs, as the two-year colleges do. We may also want to seek them from among business and policy leaders. Already, 14.7 percent of presidents come from outside higher education, while 12.8 percent are senior executives from finance or administration and 6.9 percent are executives from development, external affairs and student services (Corrigan, 2002). Presidents from outside academia can bring in fresh perspectives on our fast-changing economy as well as ideas to enhance the future success of graduates. A Latino business executive, for instance, might better understand the new jobs arising in fields like lean manufacturing and help shift the curriculum toward them, giving graduates more cutting-edge employment opportunities.

We must be careful not to raise expectations too high. College presidents face many constraints. As Franklyn Jenifer, former president of the 
University of Texas at Dallas, says,

The management structure of colleges and universities does not lend itself to rapid change. These institutions are, for the most part, governed by a collegial collective of boards, president, faculty organizations, and students. And, unfortunately, since everyone is in charge, too often that means no one is in charge. The boards say they are supportive of strong presidential leadership, but also too often they give peace on campus a higher priority. All of this serves to make the transformation of our institutions, in anything like a revolutionary way, impossible. Instead, what we are witnessing is change in an incremental or ad hoc fashion. (p. 26)

Even so, Latino presidents have an unprecedented opportunity to advance change through consensus-building itself, on a wide scale. Given the need to keep our knowledge economy flourishing in a competitive, globalizing world, they can partner with business to build agreement in society about not just the importance of minority college graduation, but the immediate necessity. The arguments have never been so compelling and the opportunities for corporate financial assistance — to both universities and leadership programs - have never been so clear. Especially in four-year institutions, Latino presidents and leadership programs can play a key role in helping the nation move forward in the 21 st century. 
The Hidden Rung: The Role of Leadership Programs

Though little known, leadership programs in higher education play a key role in the hiring of top administrators. ${ }^{7}$ For instance, these institutes can show talented individuals how to prepare for college presidencies. They can explain the qualities a president needs, convey basic necessities for performing the job well, and provide practice in key techniques such as interviewing. They can also help forge important relationships. All in all, these programs themselves are rungs on the ladder, helping able individuals move into executive positions.

They also fill a gap. Few graduate programs address the array of leadership skills that higher education leaders need to handle the complexities of their positions (Brown, Martinez, \& Daniel, 2002). Aside from these institutes, aspirants can only learn on the job or in a closely associated position. Hence it is not surprising that many individually feel inadequately prepared when they assume the mantle of presidency (Brown, Martinez \& Daniel, 2002; Raines \& Alberg, 2003; Selingo, 2005).

The institutes below tend to share certain characteristics. For instance, they typically rely on foundations for funding, especially at the outset. They focus on building support networks and provide instruction in basic areas like finance. But they also vary on many counts, especially length, structure, experience level addressed, and extent of firsthand contact with top administrators. 
The programs fall into two categories: longstanding institutes that focus on either all candidates or women, and more recent ones that address minorities.

The Mainstream Programs

There are four major leadership programs in the first category: The American Council on Education (ACE) Fellows Program; the Harvard Institutes for Higher Education (HIHE); the HERS, Mid-America Summer Institute for Women in Higher Education; and the HERS, New England Management Institute for Women in Higher Education. Combined, they have existed for 136 years. Since most lie in New England, there may be opportunities to establish similar programs elsewhere.

The Yearlong Participatory Model: The American Council on Education (ACE) Fellows Program

The ACE Fellows Program is the pioneer in this field, the oldest program and the most extensive. Created in 1964, with the help of a $\$ 4.75$ million grant from the Ford Foundation, it has aided the careers of 1,500 individuals, and drawn support from a spectrum of institutions. It offers the closest thing to an apprenticeship among these models.

The program lasts an entire year, and though Fellows can opt to take part for a semester or on a periodic basis, most enroll in the full program. Indeed, long-term eyewitness and participatory experience are central to the 
Fellows Program. Fellows watch presidents as they carry out their jobs and take part in decision-making meetings at the top level, where they hear the analysis of options available to a president.

Mentoring is a key component of the program. One Fellow remarked that her mentor was "deliberately transparent, which permits me to observe him both in moments of confidence and of uncertainty" (cited in Smith \& Ross, 2005, p. 115). Such openness is obviously extremely valuable to a Fellow.

A variety of pedagogic techniques enrich the experience, including learning contracts, reports, and seminars. Fellows prepare and sign a contract, along with the nominator and mentor, setting forth the Fellow's objectives in the program, means to achieve them, and the questions she would like it to answer. Fellows also write two reports detailing their progress toward their objectives, and in general reflecting on their experiences in leadership, administration, and decision making. In addition, Fellows participate in three weeklong seminars, on themes such as: leadership and institutional change, campus diversity, strategic planning, the business of higher education, academic planning and management, technology issues, personal and professional dimensions of higher education administration, and external forces affecting higher education.

The program fosters breadth as well. It encourages Fellows to visit other campuses and attend national conferences unrelated to their disciplines. In addition, each class takes a trip abroad where they meet leaders in higher 
education in such nations as Jamaica, United Kingdom, South Africa, Cuba, and Hungary.

The program brings benefits to all: nominators, mentors, and Fellows. The nominator gains an individual who is prepared and ready to assume a variety of campus assignments, often with fresh ideas and a more extensive network of contacts. The mentor benefits from the Fellow's work on special projects, as well as their new perspectives and contacts beyond the university. And Fellows themselves receive invaluable on-the-job training that can transform lives and careers. Of the nearly 1,500 Fellows to date more than 260 have become presidents and chancellors of 300 colleges, universities, and systems.

Though white males comprised the bulk of its classes early on, today it is significantly more diverse, and the 40th class of 38 Fellows in 2004-05 comprised 23 women and 15 men, including eight African Americans, four South Africans, two Hispanics, two Asian Americans, and one Kenyan. From 1995-96 through 2004-05, 62 percent of the Fellows were white, 24 percent African American, seven percent Hispanic, four percent Asian American, one percent Native American, and one percent multiracial.

With its length and depth, the ACE Fellows Program is probably the most expensive in the nation. Home institutions, host institutions, and ACE all share its cost. Home institutions cover the Fellows' salary and benefits, host institutions pay a program fee and defray the Fellows' professional development expenses, and ACE pays for the program's infrastructure. 
Substantial awards from corporations and foundations have helped support the program.

The Four Audiences Model: The Harvard Institutes for Higher Education (HIHE)

The HIHE tailors its offerings to discrete groups according to their immediate needs and their role in the administrative structure. Begun in 1970 with grants totaling $\$ 300,000$ from the Alfred Sloan Foundation, HIHE is a quartet of summer institutes: the Seminar for New Presidents, the Institute for Educational Management, the Management Development Program, and the Institute for Management and Leadership in Education.

The six-day Seminar for New Presidents is a form of information boot camp for, as its name indicates, first-time university heads. Even sophisticated administrators may need guidance once they reach the top, and the curriculum addresses issues such as governance and board relations, building and managing top leadership, institutional advancement, financial management, and the personal demands of the office.

The two-week Institute for Educational Management focuses on the senior management team, including experienced presidents as well as provosts and others. The institute deals with the essentials of top leadership, including governance, financial management, campus diversity, building an effective team, the commercialization of academe, and strategies for mobilizing change through action plans. 
The two-week Management and Leadership in Education Institute addresses experienced vice presidents and deans who see themselves as change agents. The curriculum focuses on leadership, financial management, strategic alliances, institutional partnerships, planning, and transformational learning.

Finally, the two-week Management Development Program aims at mid-level managers early in their careers. Its curriculum covers leadership, team effectiveness, campus community and diversity, academic administration, institutional values and integrity, financial management, strategic mentoring, planning, and fostering innovation and change.

Typically, 450 to 500 participants attend the HIHE institutes each year, and a total of over 7,000 have graduated since 1970. In a retreat-like atmosphere, HIHE offers a curriculum based on over 200 higher education case studies and discussions developed by Harvard Graduate School of Education faculty. HIHE also helps maintain social networks after the institutes end, and its alumni activities keep participants in touch with each other and with advances in the field.

Participants rate the institutes very highly. They especially appreciated six facets of the programs: enhanced context knowledge, developing a network of peers, personal and professional reaffirmation, practical application, multi-faceted learning experience, and opportunity for reflection and renewal.

HIHE has actively sought a diverse population. From 2000 to 2004, 
one-fifth to one-third of participants were people of color, for a total of 426 minority executives. HIHE has also gained funding to help administrators from Historically Black Colleges and Universities (HBCUs) and Tribal Colleges and Universities (TCUs) attend its summer core institutes.

The Monthlong Model: The HERS, Mid-America Summer Institute for Women in Higher Education

The Summer Institute helps women attain positions as middle and top university administrators. ${ }^{8}$ Begun in 1976 with funding from the William $\mathrm{H}$. Donner Foundation, the Institute provides university management skills and information for participants, helps them identify career goals, and spurs them to reach those objectives.

The four-week program on the Bryn Mawr College campus provides four central benefits:

1) Training in the governance of colleges and universities, with focus on long-range planning, decision-making processes, accounting and budgeting, information technology, and policy implementation.

2) Information on vital issues in higher education today, particularly diversity.

3) Professional development strategies, including career planning, leadership, self-presentation, and institutional change.

4) A support network of peers and mentors.

The Institute features units on the academic environment, the 
surrounding community, the institution itself, and professional development, as well as topics that students express interest in.

In 2006 the Institute charged residents $\$ 6,800$ (for room and board, tuition, and instructional materials) and commuters $\$ 5,800$. Most participants received full or partial financial support from either their home institutions or other organizations.

Since 1976, nearly 2,000 women, faculty and administrators from throughout the United States, Canada, South Africa, Saudi Arabia, Virgin Islands, Bermuda, Nigeria, Sweden, Wales, Iran, and the Netherlands have taken part in the Summer Institute.

The Five-Weekend Model: HERS, New England Management Institute for

\section{Women in Higher Education}

This smaller institute offers an appealing model for programs with fewer resources than those above. ${ }^{9}$ Begun in 1978 , it enjoys close ties with the Summer Institute, and similarly seeks to prepare women for deanships and other senior administrative posts. However, it is shorter, taking place in five weekend seminars spaced out from October through April at Wellesley College. Despite its brevity, it offers key advantages. Participants can do extensive homework, for instance, as well as apply new skills immediately on their jobs and report back with questions or comments. They gain many of the benefits of longer programs without the time commitment.

The program focuses on three areas: finance, management, and 
professional development. Enrollees tend to have titles such as administrator, coordinator, director, assistant to the president, comptroller, registrar, assistant and associate dean, and chair. Dean and vice presidents are less common. Each year about 50 women participate in the course, and in 2005 they came from almost 40 universities. Home institutions financed 96 percent of attendees, wholly or partially. Overall, some 1,200 women, primarily from the five New England states, have taken part in the program so far.

The New Leaders: Programs Focused on Minorities

The leadership programs below are relatively new, and they sprang up in part because the mainstream programs were not sufficiently addressing minority needs. Established programs have tended to focus on topics such as administration, technological change, and marketing. While essential, these are not enough for Latino candidates. For instance, the institutes below place greater emphasis on real-world experience, including direct contact with minority presidents and other administrators. Minority aspirants find the insights of these leaders about their own careers especially valuable. Unfortunately, funding problems have struck some of these programs and one has recently shut down. Support from grantors will likely be a key concern as these institutes move forward.

The Workshop Model: HACU Latino/a Higher Education Leadership Institute This institute is currently the only one aimed squarely at Latinos, and it 
is the least expensive of all the programs discussed here. The idea came from the summer leadership program one of us (León) attended in 2001. It focused on Asian Pacific Americans, ${ }^{10}$ and León envisioned a similar program for Latinos, since none then existed. It began as a one-day workshop just before the annual meetings of the Hispanic Association of Colleges and Universities (HACU).

The HACU Leadership Institute is now in its fifth year. It began with ambitious goals for a single day: To provide demographic data on the prevalence of Latinos in society and their paucity in higher education, to examine career development issues and provide exercises, to discuss policy questions and administrative trends in higher education, and to hear Latino presidents speak about their own career paths and trends for Latino students. Participants in the first Institute gave the highest ratings to both the president's panel and small groups focused on career development issues. It was clear that they appreciated the Institute and they asked that it be longer.

As a result, the second Institute lasted two days. It included a new panel on Latinas and another on fundraising, and it extended the time for small group discussions. The Institute dropped the panel on demographics and the case studies of Latino presidents. However, attendance at this event declined from 34 to 19. Cost may have caused this falloff, since the registration fee doubled at a time when many institutions faced state budget cutbacks and were curbing travel. Participants gave the highest rating to the fundraising, career development, and presidents' panels. 
Given the low participation rate, we returned to a one-day format. The third Institute attracted 23, a slight improvement from the prior year. The toprated panels were the president's panel, Core Values/Coraje in Latino/a Leadership, and the hands-on workshop.

The most recent Institute attracted 30 participants, a clear increase over the previous year. The latest format includes an opening speech by a Latino president who discusses the current state of Latinos in higher education. Next comes a hands-on segment focusing on review of vita, discussion of career paths, explanation of elements of an effective letter of application, and interviewing tips. We divide participants into two groups, according to whether their background is academic affairs or student affairs. In the afternoon we hold two panels. One addresses an area of concern and the other, final panel is composed entirely of Latino presidents.

Although the Institute is a work-in-progress, it has met a clear demand. As a result, it is now a regular pre-conference activity for HACU's annual meetings. The Institute will likely see further adjustments in coming years.

The Training-Plus-Mentoring Model: The Millennium Leadership Initiative $(M L I)$

Though relatively new, the MLI is the oldest existing program developed by minorities for minorities. It lasts four days, with a one-year follow-up of mentoring from current presidents. Given its brief history so far, it also boasts an impressive record. 
On February 12, 1999, a group of African-American presidents and chancellors met at the headquarters of the American Association of State Colleges and Universities (AASCU) to create the MLI. They took inspiration from Walker Percy's 1961 novel The Moviegoer, which stresses that we are all responsible for "handing one another along."

The founders asked basic questions: How are minority candidates different? How do existing programs fail to meet their needs? How could they themselves equip minority candidates to succeed in an executive search system? How would they recruit talented veteran presidents to pass along their insights? Ultimately, they decided that MLI would provide people of color with a high-level, comprehensive preparation program.

To launch it, MLI aimed marketing efforts at African Americans, Latinos, Asian Pacific Americans, and women. Most applications have come from individuals encouraged to apply by AASCU member presidents and from MLI graduates themselves. From 1999 to 2004, MLI graduated 181 individuals composed of 123 African Americans (68.0 percent), 10 Latinos (5.5 percent), 7 Asian Pacific Americans (3.9 percent), one Native American (0.6 percent), and 40 Whites (22.1 percent). To be eligible, applicants must receive the endorsement of an AASCU current or former president and chancellor. A subcommittee of AASCU presidents and chancellors screens applications and decides whom to admit.

The MLI consists of a four-day professional development institute followed by a year of mentoring with a current or former president. This 
structure keeps the total time commitment relatively short, while allowing the benefits of a long-term program. The curriculum helps participants gauge and enhance their skills, identify areas for improvement, gain assistance in developing career strategies, and find a mentor for the next step, the executive search process.

The Institute supports "pay it forward": not just paying a favor back, but passing it on to three new persons unknown to the giver. Many people invest in the summer institutes: AASCU member institutions support them financially, while presidents and chancellors nominate candidates, serve on MLI selection committee, and act as experts and mentors. The participants are unaware of who invested in them until they arrive at the Institute. They are expected to "pay it forward" when the chance presents itself.

The Institute's pragmatic curriculum begins with executive search firms. Participants compose letters of intent, write effective cover letters and resumes, evaluate and decipher position descriptions, and hone their interview etiquette and techniques. Well-regarded search firm executives and experienced presidents offer guidance to avoid pitfalls. The other areas include: negotiating the executive contract, financial management, advancement and fundraising, communicating one's message to advance the institution, working with Congress, lessons on leadership, campus diversity, and working with governing boards.

The professional development plan is basic to MLI. Presidential advisors critique participants' plans, and attendees say this feedback is "one of 
the most unique and powerful elements of the institute" (cited in Lauth, 2005, p. 162-3). The advisors help their proteges answer four basic questions: Where am I now? Where do I want to be eventually? What do I need to do to get there? What's my first step on that journey?

After the four-day Institute, a volunteer presidential mentor continues the conversation with each participant. Mentors often invite their proteges for a campus visit (which includes meetings with senior staff and community leaders), serve as a liaison to connect participants to other people and resources, and refine their professional development plans. Mentors also provide mid-year progress reports and final evaluations. As of 2006, 32 of its 251 proteges had achieved presidencies, and one-third had made significant advances in their careers. It is an impressive achievement.

\section{The MSI-Based Model: The Kellogg MSI Leadership Fellows Program}

The Kellogg MSI Leadership Fellows Program no longer exists, but it is worth describing partly because it offered the only other Latino leadership institute in the nation. It focused on renewing leadership at Minority Serving Institutions (MSIs) — those colleges identified by federal legislation as serving minority groups who suffered from historical segregation and educational deprivation. Like MLI, this program provided a brief period of instruction followed by a yearlong mentorship.

In 1999, the Alliance for Equity in Higher Education was formed and the three principal members included HACU, the American Indian Higher 
Education Consortium (AIHEC), and the National Association for Equal Opportunity in Higher Education (NAFEO). Their member institutions include Hispanic Serving Institutions (HSIs), Historically Black Colleges and Universities (HBCUs), and Tribal Colleges and Universities (TCUs). HACU represents more than 200 institutions, in 14 states, Puerto Rico, and six foreign countries; NAFEO represents 118 HBCUs; and AIHEC represents 35 Tribal Colleges in the United States and one in Canada. Together the alliance contains 350 MSIs and serves two million students. Though each organization serves a separate population, the Alliance draws them together to cooperate rather than to compete for scarce resources.

These organizations recognized the need for a leadership program to prepare the next generation of senior administrators for MSIs. Since many presidents and senior level administrators in MSIs will be retiring in the next 10 years, leaders of the Alliance pledged to identify and mentor the next generation.

The program commenced in the fall of 2002 with the support of a $\$ 6$ million, four-year grant from the W.K. Kellogg Foundation. Together the Alliance and the Foundation created the MSI-Kellogg Leadership Fellows project. A project team designed and implemented the program. It printed application materials and created and sent promotional packages to all MSI presidents.

The curriculum was based on a yearlong mentorship between Fellows and MSI presidents where they work together on a mutually agreed upon 
project.

The first class took place in 2003-2004 with the Institute Week in Washington, D.C. The coming together of three communities was a symbolic and emotional launch to the program, with receptions, dinners, panels, and guest speakers. For example, the Fellows visited Tribal Colleges in North Dakota, and HSIs and HBCUs in Florida. The final joint seminar took place in Mexico City, where the Fellows heard a lecture about indigenous colleges in Chiapas and visited Ibero-Americano University.

The first year-evaluations from the Fellows were very favorable. They responded well to the speakers and felt privileged to be part of this historic program, and they cited a network of new colleagues as the most beneficial aspect of the program.

The Fellows also met seven to eight times during the year, and these meetings fell under three general headings: planning and strategic issues, dayto-day concerns, and principles of leadership. However, the topics discussed were wide-ranging, and included: membership associations and advocacy organizations, legal and regulatory issues, board relations and cultivation, information technology, senior staffing, time management and priority setting, serving as an effective change agent, crisis management and conflict resolution, gender conflict and gender roles, ethics, personal motivation and vitality, and public speaking and advocacy.

In its first two years, the program was in high demand, with more applications than the available 30 slots. The Institute selected ten Fellows from 
each of the three communities. The Fellows, mentors, and nominating presidents signed both the Fellowship Agreement and Learning Agreement.

The HACU component of the program dealt with the experiences of Latino administrators and the conflicts they encounter, making them a basic part of the discussion and problem-solving exercises.

At launch, the program sent application packets to all 415 HACUmember institutions, and received more applications than it could accommodate with the ten available Fellowships. To qualify for the program, each candidate first had to receive nominations from their campus presidents. Selection then depended on the applicant's potential, as determined by her Learning Plan, qualifications, terminal degree, essay, recommendations, publications, honors, and awards.

The HACU program covered a wide array of topics, including development of vision and mission; leadership and change; board relations, shared governance, and planning policy and strategy; critical issues in higher education policy; development and fundraising; national policy perspectives; and advocacy groups in higher education. Participants also attended the HACU Capitol Forum. An important addition to the curriculum involved Latino women. Two-thirds of the student population at HSIs are Latina and therefore HACU's leadership program had to highlight gender-based issues.

A key aspect of the program involved matching Fellows with HACU presidents. Mentoring began early in the program and the mentors invited the Fellows for a campus visit. 
The MSI Kellogg program, including the HACU component, ended in 2006 after the four years of funding elapsed.

The Faculty- and Staff-Oriented Model: The Leadership Development Program in Higher Education (LDPHE)

The LDPHE focuses on Asian Pacific Americans (APA's). Large numbers of them attend America's most prestigious institutions and many seem to have achieved the American Dream. Yet few have become university administrators. The LPDHE model focuses on developing leaders from among faculty and staff, since the ranks of mid-level APA managers are thin.

The LDPHE began taking shape in 1995, under the leadership of Bob Suzuki, then President of California State Polytechnic University, Pomona. President Suzuki asked J.D. Hokoyama, president and CEO of Leadership Education for Asian Pacifics, Inc. (LEAP), to provide the working structure for LDPHE.

The LDPHE held its first class of 25 in June of 1997. It was an intensive, four-day summer workshop featuring in-depth interactions between participants and program faculty. There, APA college presidents and other senior administrators expressed the concern that, though APA's had the credentials and technical knowledge for university executive positions, most lacked the assertiveness, communication, and leadership skills. Hence, LDPHE focuses on these areas. Key sessions include: Developing and Promoting Your Leadership Style, Mastering the Dynamics of Power, 
Understanding Asian Pacific American Values and Leadership Skills, Effective Communication Strategies, Interviewing for Success (with practice interviews), Risk Taking-Making Changes Happen, Successfully Surviving Leadership Challenges, and The 21st Century Leader: Surviving and Thriving in the Third Millennium.

LDPHE participants create a Leadership and Career Action Plan for themselves, and revise it each day of the Institute. The Plan entails some introspection and includes: personal Institute goals (day one to day four), identification of the leadership qualities the participant values, and selfassessment of one's own qualities, such as leadership skills, general strengths and weaknesses, options, and obstacles. The Plan also embodies the participant's personal road map.

From 1997 to 2004, about 190 attended the summer institute, primarily Chinese, Japanese, and Filipinos. Over three-quarters (76 percent) have been mid-level administrators and staff, and LDPHE realizes that it must attract more APA faculty.

In their evaluations, participants said they appreciated the interaction with their mentors, the guest speakers, the conversations with other APA staff and faculty, and the overall usefulness of the experience to their careers. They disliked the cost and length of the program, and felt the handouts could have been more useful. Funding problems continue to afflict the program. Followup activities with program alumni have occurred in 2003 and 2004, in sessions parallel to the regular program. 


\section{Recommendations}

No single strategy will sufficiently increase the number of Latino presidents, but minority-oriented leadership institutes are an important step. The recommendations below - greater focus on philanthropic opportunities, stronger ties with positive businesspeople, active support of leadership institutes from presidents and governing boards, more transitions from twoyear college presidents to four-year positions, greater numbers of Latino faculty, and more information on the experience of top Latino leaders - are all crucial elements in developing Latino leaders.

Leadership institutes, especially those addressing minorities, need more effective outreach to philanthropic organizations. Lack of funding has undermined some institutes, yet their mission should appeal to grantors on a number of grounds. For instance, Latino leaders can help improve the graduation rate and break the cycle of poverty. Enormous funder resources already go into impoverished neighborhoods, often to treat immediate problems, but this investment strikes at a cause. In addition, funders will be helping influential individuals, who will remember their generous contributions.

Leadership institutes should form alliances with business partners. As noted, many business leaders are seriously concerned about the low Latino 
graduation rate. This fact marks a significant shift from the past and holds out the prospect of broad, mainstream support for this critical issue. Indeed, it is one of the major changes in the history of minorities in this country, and we must take advantage of it. Many corporations have philanthropic arms, of course, and they can help support leadership institutes. In the university itself, the relationships can go further, and the business world may directly provide some of the Latino presidents we need.

Urge presidents and governing boards to assume greater responsibility for developing Latino leaders. Universities, and especially university systems like the University of California, can establish or support leadership programs for tenured faculty and mid-level administrators. Universities should of course also take steps to place graduates in appropriate administrative positions.

Seek more Latino four-year college leaders from among two-year college presidents. Though the channeling of Latino leaders to two-year colleges is in many ways unfortunate, these institutions provide an invaluable training ground for four-year college presidents. As noted above, many college presidents arrive at their jobs unprepared, yet these Latino executives already know the position. Universities should recruit them directly.

Increase the number of Latino faculty. The tightest bottleneck on the route to Latino presidencies lies at the level of tenured faculty. There are many urgent 
reasons to widen it, especially the coming surge in Latino enrollments. Hence, institutions of higher education must recruit Latino faculty more effectively. They should develop a recruitment plan that attracts diverse candidates, use creative recruitment strategies, have minority representation on the search committees, and use the diversity officer and human resources department to assure equity in the search process.

Assess the experience of Latinos in top leadership positions. We need to know more about how Latino leaders obtain and carry out executive positions, to help increase the pool of Latino executives and ensure their success.

\section{Conclusion}

The number of Latino college presidents must triple if they are to reflect the Latino presence in U.S. society. Their relative absence is a serious problem for society, since it affects the whole perspective of a university and ultimately diminishes the nation's ability to compete economically. Leadership institutes are one solution. They build the skills and confidence of participants by providing them with the insight and tools needed to apply effectively and lead ably. Institutes oriented toward minorities play an especially important role. Overall, the institutes vary in structure and approach, and this paper has outlined the models with the hope of giving current and future programs a better understanding of their options. It has also made recommendations for improving the institutes and Latino representation 
in presidencies generally. Latino leaders have proven their ability to positively influence the educational outcomes of students in diverse contexts. With support, leadership institutes will continue to offer a helping hand to future Latino executives, and benefit them, institutions of higher education, and society at large. 


\section{References}

Bay Area Economic Forum (2006, February). The innovation economy: Protecting the talent edge. Retrieved January 31, 2007, from: www.bayeconfor.org/keypub.html.

Berlak, A., \& Moyenda, S. (2001). Taking it personally: Racism in the classroom from kindergarten to college. Philadelphia: Temple University Press.

Brown, L., Martinez, M., \& Daniel, D. (2002, Summer). Community college leadership preparation: Needs, perceptions, and recommendations. Community College Review, 30, 45-73.

Chemers, M. M., \& Murphy, S. E. (1995). Leadership and diversity in groups and organizations. In M. M. Chemers, S. Oskamp, \& M. A. Costanzo (Eds.), Diversity in orgnizations: New perspectives for a changing workplace. Thousand Oaks: Sage Publications.

Chen, C. C., \& Velsor, E. V. (1996). New directions for research and practice in diversity leadership. Leadership Quarterly, 7(2), 285-302.

Corrigan, M. (2002). The American college president: 2002 edition. 
Washington D.C: American Council on Education.

Delgado-Romero, E.A., Flores, L., Gloria, A., Arredondo, P., \& Castellanos, J. (2003). The majority in the minority: Developmental career challenges for Latino and Latina psychology faculty. In J. Castellanos \& L. Jones (Eds.), The majority in the minority: Retaining Latina/o faculty, administrators, and students in the 21st century (pp. 257-283). Sterling, VA: Stylus Books.

Fry, R. (2005, November 1). The high schools Hispanics attend: Size and other key characteristics. Washington, DC: Pew Hispanic Center. Retrieved January 31, 2007, from: pewhispanic.org/reports/report.php?ReportID=54.

Haro, R., \& Lara, J. (2003). Latinos and administrative positions in American higher education. In: J. Castellanos \& L. Jones (Eds.), The majority in the minority: Retaining Latina/o faculty, administrators, and students in the 21st century (pp. 153-165). Sterling, VA: Stylus Books.

Harvey, W. B. (2003). Minorities in higher education annual status report. Washington, DC: American Council on Education.

Hooijberg, R., \& DiTomaso, N. (1996). Leadership in and of demographically 
diverse organizations. Leadership Quarterly, 7(1), 1-19.

Jenifer, F. G. (2005). Minorities and women in higher education and the role of mentoring in their advancement. Report prepared for the Office of Academic Affairs, University of Texas System. Retrieved January 29, 2007, from: www.utsystem.edu/aca/files/Mentorship.pdf.

June, A. W. (2007, February 16). Presidents: Same look, different decade. Chronicle of Higher Education. Retrieved February 26, 2007, from: chronicle.com/temp/email2.php?id=VqwrfBGNQqnNk96cjyRdXxdPg Wwj3t3P.

Ladson-Billings, G. (1994). The dreamkeepers: Successful teachers of African American children. San Francisco: Jossey-Bass.

Lauth, R. (2005). Handing one another along: The creation of AASCU's Millennium Leadership Initiative. In D. J. León (Ed.), Lessons in leadership: Executive leadership programs for advancing diversity in higher education (pp. 151-172). London: Elsevier.

León, D. J. (Ed.). (2003). Latinos in higher education. London: Elsevier.

León, D. J. (Ed.). (2005). Lessons in leadership: Executive leadership 
programs for advancing diversity in higher education. London:

Elsevier.

León, D. J. \& Nevarez, C. (2006). Chicano Latino Intersegmental Convocation declaration: Promoting Latino faculty and senior-level administrators. Paper presented at the 2006 Chicano/Latino Convocation Policy Summit.

Lopez, E. S., \& Reyes, B. (2004). Faculty managers and administrators in the University of California 1996 to 2002. Sacramento, CA: California Research Bureau.

Madsen, J. A. \& Mabokela, R. O. (2002). Introduction: Leadership and diversity: Creating inclusive schools." Peabody Journal of Education, 77(1), 1-6.

Martinez, R. O. (2005). Latino institutional and demographic issues in higher education: Implications for leadership development. In D. J. León (Ed.), Lessons in leadership: Executive leadership programs for advancing diversity in higher education (pp. 17-56). London: Elsevier.

Medina, C., \& Luna, G. (2000). Narratives from Latina professors in higher education. Anthropology \& Education Quarterly, 31(1), 47-66. 
National Science Foundation (2006, December). Women, Minorities, and Persons with Disabilities in Science and Engineering. Table H-6: Employed scientists and engineers, by occupation, highest degree level, and race/ethnicity: 2003. Retrieved January 31, 2007, from: www.nsf.gov/statistics/wmpd/race.htm\#employ.

Nieves-Squires, S. (1991). Hispanic women: Making their presence on campus less tenuous. Washington, DC: Association of American Colleges and Universities.

Nevarez, C., \& Borunda, R. (2007). Professors of color and their students: Negotiating the classroom domain. Manuscript submitted for publication.

Orfield, G., Losen, D., Wald, J., \& Swanson, C. (2004). Losing our future: How minority youth are being left behind by the graduation rate crisis. Cambridge, MA: The Civil Rights Project at Harvard University.

Paddock, R.C. (2007, January 15). For many minorities, UC Riverside is the campus of choice. Los Angeles Times. Retrieved January 31, 2007, from: www.latimes.com/news/local/la-meriverside15jan15,1,1861741,full.story. 
Raines, S.C., \& Alberg, M.S. (2003). The role of professional development in preparing academic leaders. New Directions for Higher Education, $124,33-39$.

Reyes, M. de la Luz, \& Halcon, J.J. (1988). Racism in academia: The old wolf revisited. Harvard Educational Review, 58(3), 229-314.

Schoem, D., Frankel, L., Zuniga, X., \& Lewis, E. A. (Eds.). (1993). Multicultural teaching in the university. Westport: Praeger.

Selingo, J. (2005, November 4). Leaders' views about higher education, their jobs, and their lives. Chronicle of Higher Education, 52(11), A26.

Smith, D. G., \& Moreno, J. F. (2006, September 29). Hiring the next generation of professors: Will myths remain excuses? Chronicle of Higher Education, 53(6), B22.

Smith, G.A. \& Ross, M. (2005). American Council on Education Fellows Program: Celebrating 40 years of leadership development in higher education. In D.J. León (Ed.), Lessons in leadership: Executive leadership programs for advancing diversity in higher education (pp. 109-126). London: Elsevier. 
Tatum, B. D. (1997). Why are all the black kids sitting together in the cafeteria? And other conversations about race. New York, NY: Basic Books.

Turner, C. S. V., \& Myers, S. L., Jr. (2000). Faculty of color in academe: Bittersweet success. Boston: Allyn and Bacon.

U.S. Census Bureau (2005). College degree nearly doubles annual earnings, Census Bureau reports. Retrieved February 1, 2007, from: http://www.census.gov/ Press-Release/www/releases/archives/education/004214.html

U.S. Census Bureau (2006). Facts for features, Hispanic heritage month 2006: September 15-October 15. Retrieved January 29, 2007, from: http://www.census.gov/Press-Release/www/releases/archives/ facts_for_features_special_editions/007173.html.

U.S. Department of Education, National Center for Education Statistics (20032004). Integrated Postsecondary Education Data System (IPEDS), Fall Staff component.

U.S. Department of Education, National Center for Education Statistics 
(2005). Table 224. Employees in degree-granting institutions, by race/ethnicity, residency status, sex, employment status, control and type of institution, and primary occupation: Fall 2003. Retrieved January 31, 2007, from: http://nces.ed.gov/programs/digest/d05/tables/dt05_224.asp.

U.S. Department of Education (2006, September). A test of leadership: Charting the future of U.S. higher education. Jessup, MD: Education Publications Center.

Valverde, L.A. (2003). Leaders of color in higher education. New York: AltaMira Press.

Vaughan, George B. (2004, October 29). Diversify the presidency. Chronicle of Higher Education. 
Notes

1. The figures exceed 100 percent because the U.S. Census Bureau counts Latinos as an ethnic category, apart from racial figures. One can be Latino and black, for instance.

2. They are also the fastest growing minority group, and their numbers increased by 3.3 percent over this period (U.S. Census Bureau, 2006).

3. In 2005 Latinos had a median age of 27.2, compared to 36.2 for the U.S. overall.

4. There is some discrepancy among the figures as well as apparent change over the years. According to Vaughan (2004), 4.9 percent of higher education presidents in 1996 identified themselves as Hispanic and 5.2 percent as black, but by 2001 those proportions had increased to 5.5 percent and 6.4 percent respectively. Martinez (2005) observes that as of Fall 2001, Latinos were only 3.7 percent of college or university presidents in comparison to 6.3 percent blacks and 87.2 percent whites.

5. See Valverde (2003, p. 95).

6. See, for instance, the most recent biannual report of the Bay Area Economic Forum (2006, Feb.).

7. This section and the one following rely heavily on D. León (2005).

8. Information on this program comes from www.brynmawr.edu/summerinstitute. Accessed January 31, 12007. 9. Information on this program comes from 
www.wellesley.edu/WCW/Hers/Frm_Home.htm. Accessed January 31, 2007.

10. See León (2003) for his description of his experience as the sole nonAsian attending this institute. 